\title{
Effect of Prior Austenite Grain Size on High Temperature Creep Properties of a $\mathrm{Cr}^{-} \mathrm{Mo}^{-} \mathrm{V}$ Steel
}

Kazuhiro KImURA, Narihito OHI, Takashi Matsuo, Makoto KIKUCHI and Ryohei TANAKA

\section{Synopsis :}

The creep tests for the specimens with the various prior austenite grain sizes $(10,26,52$ and $106 \mu \mathrm{m}$ in diameter) have been carried out at $650^{\circ} \mathrm{C}-6 \sim 17 \mathrm{kgf} / \mathrm{mm}^{2}$ to investigate the effect of the prior austenite grain size on high temperature creep properties of a $1 \mathrm{Cr}-1 \mathrm{Mo}-1 / 4 \mathrm{~V}$ steel.

The minimum creep rate decreased linearly with increasing prior austenite grain diameter up to $50 \mu \mathrm{m}$. This increase in the creep resistance was proportional to the decrease in the volume fraction of the recovered zone along the prior austenite grain boundaries. In the specimen with prior austenite grain diameter larger than $50 \mu \mathrm{m}$, however, the creep resistance did not follow the linear increase with the grain diameter, because of the formation of large cracks at higher stress, and the marked increase in the recovered zone width at lower stress due to the microstructural inhomogeneity.

The prior austenite grain size should be controlled to be below $50 \mu \mathrm{m}$ in diameter to optimize the creep resistance of a $\mathrm{Cr}-\mathrm{Mo}-\mathrm{V}$ rotor steel for the long term service.

Key words : creep; grain size; steel for elevated temperature service; creep resistance ; prior austenite grain size ; recovered zone ; Cr-Mo-V steel ; microstructural inhomogeneity.

\section{1. 緒言}

現在，長時間使用された火力発電プラントに代表され るように，高温構造用部材の余寿命を推定するという観 点から, 耐熱鋼の高温使用に伴う材料劣化を的確に把握 するための研究が活発におこなわれている1) 9).

木村らは, クリープによる損傷が問題とされている $\mathrm{Cr}-\mathrm{Mo}^{-} \mathrm{V}$ 鋼のタービン・ローター材を取りトげ,この 材料の高温長時閒使用にともなう強度低下が割れや空泡 の発生に起因した機械的損傷によるのではなく，軟化現 象に基づいた材質少化によることを明らかにした7) 99. すなわち, 実機蒸気タービンローターから切り出した

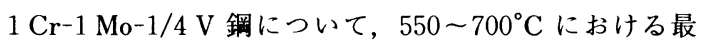
長 $10000 \mathrm{~h}$ までの単純時効及びクリープ試験をあらか じめ実施し, これらの試料について, クリープ抵抗の評 価及び組織調査を系統的に行つた。 それらの検討より, 高温使用によるこの鋼のクリープ抵抗の低下はこれまで その主因子とみなされてきた空泡の発生, 連結12)，あ るいはベイナイト組織の均一な軟化3) 6)によるのではな く，旧オーステナイト粒界に沿つた局所的な場所に扝い て生じた炭化物及び転位密度の著しく低いサブグレイン 及びフェライトからなる回復領域の幅の拡大という不均 一な組織変化に起因することを見いだしだ) 99. また， 単純時効材に比べクリープ試験材がより小さなクリープ

昭和 61 年 4 月本会講演大会にて発表 昭和 62 年 4 月 10 日受付 (Received Apr. 10, 1987)

* 東京工業大学大学院 (現：金属材料技術研究所) 工博 (Graduate School, Tokyo Institute of Technology, Now National Research Institute for Metals)

*2 東京工業大学大学院 (Graduate School, Tokyo Institute of Technology)

*3 東京工業大学工学部 I博 (Faculty of Engineering, Tokyo Institute of Technology, 2-12-1 Ookayama Meguro-ku, Tokyo 152)

*4 東京工業大学総合理工学研究科 (現: 横浜国立大学) 工博 (Graduate School of Science and Engineering at Nagatsuda, Tokyo Institute of Technology, Now Yokohama National University) 
抵抗を示す原因は回復領域の粒内への拡大がより進行し ていることによることも明らかにしだ（以下前報と呼 ぶ).

このように粒界から生ずる不均一な組織の拡大によつ てクリープ抵抗が決定される鋼においてはクリープ抵抗 の旧オーステナイト粒径依存性を検討する必要があると 考えられる，一般には，粒界面積が小さな粗粒材ほどク リープ抵抗は大きいと考えられており ${ }^{10111)}$ ，そのよう な結果を示した報告は多い12)13). しかし，粒界で生ず る不均‥な組織に着目して, これの結晶粒度依存性を調 べクリープ抵抗との関係を検討した報告はない。

前報で述べたように応力の負荷は旧オーステナイト粒 界に汸つて生じる回復領域という不均一な組織の粒内へ の搪大を加速する ${ }^{9}$ ．ところが，結晶粒径が増加すると 幾何学的な関係から粒界三重点での応力集中は増大す $ろ^{14)}$. したがつて，そのような不均一な組織の結晶粒 径依存性を考える場合, 粒径の増加に伴う局所的な応力 集中の増大が組織に及ぼす影響を考慮する必要がある. 近藤ら ${ }^{15)}$ は炭化物の析出を避けるため, 炭素量を 0.01 wt \% 以下に抑之，オーステナイト単相とした $17 \mathrm{Cr}^{-}$ $14 \mathrm{Ni}$ 鋼のクリープ抵抗に及ぼす結晶粒径依存性を 37 $600 \mu \mathrm{m}$ の粒径範囲について調べた。その結果, 定常ク リープ速度は結晶粒径が $100 \sim 200 \mu \mathrm{m}$ の範囲で最小と なり, 結晶粒径が $200 \mu \mathrm{m}$ を超えると粗粒のものほど大 きなクリープ速度を示すことを見出し，その原因は粒界 三重点などで再結晶粒及び粒界の張り出し（Ledge）の ような不均一な組織がすでに定常クリープ域において生 ずるためであることを明らかにしている，また，同様の 結果が Hastelloy X についても報告されている ${ }^{16)}$.これ らの知見は粒界近傍というごく限られた場所において生 じた不均一な組織变化が，結晶粒径の増加を介した応力 増加によつて加速され，それがクリープ抵抗に直接影響 を与えることを示した実証例として重要である。したが つて，高いクリープ抵抗をもたらすべイナイト組織から なる $\mathrm{Cr}-\mathrm{Mo}-\mathrm{V}$ 鋼についてクリープ抵抗の結晶粒径依存 性を検討する場合にはそのような不均‥な組織の粒径依 存性の調查が必要であると考えられる.

このような観点より，木村らは前報 ${ }^{9)} て ゙$ 用いた
$\mathrm{Cr}-\mathrm{Mo}^{-} \mathrm{V}$ 鋼についてクリープ抵抗に及ほすす旧オーステ ナイト粒径の影響を調べ，その骨子についてはすでに公 表した ${ }^{17)}$. 本論文は, 旧オーステナイト粒径を広い範 曲で変化させ，クリープ抵抗の旧オーステナイト粒径依 存性を粒界に沿つた不均一な組織の形成と関連させて検 討したその研究の詳細を述べたものである，なお，長時 間側での旧オーステナイト粒度依存性在確認するため, 旧オーステナイト結晶粒界に沿つたフェライトの形成が より活発に生ずるよう, クリープ試験は実機使用温度よ り約 $100^{\circ} \mathrm{C}$ 高い， $650^{\circ} \mathrm{C}$ の温度加速試験とした。

\section{2. 実 験 方 法}

供試材は前報9)に扔いて用いたものと同一の $1 \mathrm{Cr}^{-}$ $1 \mathrm{Mo}-1 / 4 \mathrm{~V}$ 鋼であり，その化学組成及び受け入れまま の素材に施された熱処理条件を Table 1 に示す。なお， 受け入れままの素材の旧オーステナイト粒徍は $21 \mu \mathrm{m}$ であつた。これに Table 2 に示すオーステナイト化処 理を施すことにより旧オーステナイト粒径を10〜106 $\mu \mathrm{m}$ の範囲で 4 水準に調整し，いずれもオーステナイト 化処理の最終段階で $1000^{\circ} \mathrm{C}$ より空冷した後, 受け入 れままの素材に施された条件と同…条件の焼もどしを施 した.

クリープ試験は $650^{\circ} \mathrm{C}$, 応力 $6 \sim 17 \mathrm{kgf} / \mathrm{mm}^{2}$ の範囲 で行つたが, 破断時間が $1000 \mathrm{~h}$ を超えることが予想さ れるクリ-.プ試験には標点距離 $40 \mathrm{~mm}$, 平行部径 $8 \mathrm{~mm}$ の丸棒試験片を用い，1000 h を超えない場合には，原 則として標点距離 $30 \mathrm{~mm}$, 平行部径 $6 \mathrm{~mm}$ のものを用い た.

破断材及び一部のクリープ中断材について光顕, 走査 電顕及び透過電顕による組織観察を行つた。旧オーステ ナイト粒径は光顕写真上で線分析し, テストラインと切

Table 1. Chemical composition (wt \%) and heat treatment of $1 \mathrm{Cr}^{-1} 1 \mathrm{Mo}^{-1} / 4 \mathrm{~V}$ steel studied.

\begin{tabular}{ccccccccc}
\hline $\mathrm{C}$ & $\mathrm{Si}$ & $\mathrm{Mn}$ & $\mathrm{P}$ & $\mathrm{S}$ & $\mathrm{Ni}$ & $\mathrm{Cr}$ & $\mathrm{Mo}$ & $\mathrm{V}$ \\
\hline 0.27 & 0.27 & 0.66 & 0.009 & 0.007 & 0.34 & 1.10 & 1.23 & 0.25 \\
\hline & & $970^{\circ} \mathrm{C} \times 19 \mathrm{~h} \rightarrow$ Fan cooled & & & \\
$670^{\circ} \mathrm{C} \times 52 \mathrm{~h} \rightarrow$ Furnace cooled & & & \\
$640^{\circ} \mathrm{C} \times 23 \mathrm{~h}$ & $\rightarrow$ Furnace cooled
\end{tabular}

Ingot weight : $70 \mathrm{t}$

Table 2. Heat treatment to obtain four different prior austenite grain sizes in a Cr-Mo-V steel.

\begin{tabular}{|c|c|c|}
\hline Austenitizing treatment & Tempering treatment & Prior austenite grain diameter $(\mu \mathrm{m})$ \\
\hline $\begin{array}{l}{\left[950^{\circ} \mathrm{C} \times 0.1 \mathrm{~h} \rightarrow(\text { A. C. }) \rightarrow 600^{\circ} \mathrm{C} \rightarrow 950^{\circ} \mathrm{C}\right] \times 3} \\
\quad 950^{\circ} \mathrm{C} \times 0.1 \mathrm{~h} \rightarrow 1000^{\circ} \mathrm{C} \rightarrow \text { A. C. }\end{array}$ & \multirow{4}{*}{$\begin{array}{l}670^{\circ} \mathrm{C} \times 52 \mathrm{~h} \rightarrow \mathrm{F} . \mathrm{C} . \\
640^{\circ} \mathrm{C} \times 23 \mathrm{~h} \rightarrow \mathrm{F} . \mathrm{C} .\end{array}$} & 10 \\
\hline $1000^{\circ} \mathrm{C} \times 1 \mathrm{~h} \rightarrow$ A. C. & & 26 \\
\hline $1000^{\circ} \mathrm{C} \times 100 \mathrm{~h} \rightarrow \mathrm{A} . \mathrm{C}$ & & 52 \\
\hline $1050^{\circ} \mathrm{C} \times 100 \mathrm{~h} \rightarrow($ F. C. $) \rightarrow 1000^{\circ} \mathrm{C} \rightarrow$ A. C. & & 106 \\
\hline
\end{tabular}


り合う粒界の数を測定することにより求めた。なお，旧 オーステナイト粒界を現出させるための腐食液には過飽 和のピクリン酸エチルアルコール液に塩酸及び界面活性 剤を微量添加したものを用いた。硬さ測定はビッカース 硬さ試験機を用いて, 荷重 $10 \mathrm{kgf}$ で行つた。

\section{3. 実験結果及び考察}

\section{$3 \cdot 1$ 旧オーステナイト粒径の調整}

Table 2 に示した条件でオーステナイト化观理後，焼 もどしを施した試料の光顕組織を Photo. 1 に示す. 旧 オーステナイト粒径は 10 106 $\mu \mathrm{m}$ の広い範囲に調整さ れ，粒径のばらつきも少ない。また，いずれも焼もどし ベイナイト組織を呈しているが, $106 \mu \mathrm{m}$ の旧オーステ

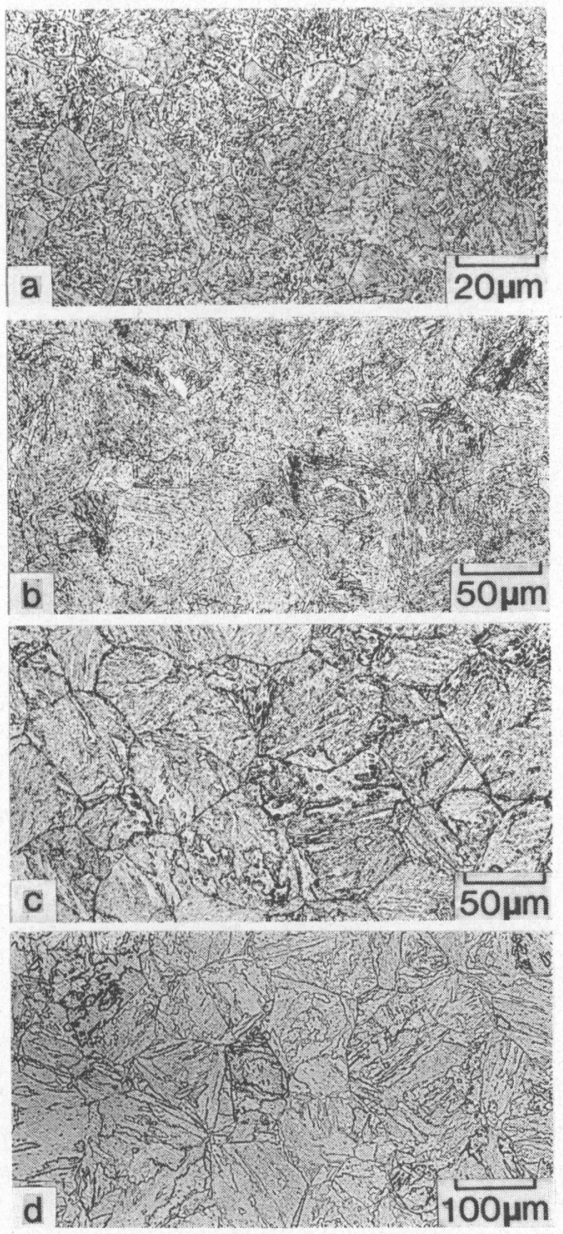

a : $10 \mu \mathrm{m} \quad$ b : $: 26 \mu \mathrm{m} \quad c: 52 \mu \mathrm{m} \quad \mathrm{d}: 106 \mu \mathrm{m}$

Photo. 1. Optical micrographs of the specimens with the prior austenite grain sizes of $10,26,52$ and $106 \mu \mathrm{m}$ after different heat treatment.
ナイト粒径を持つ試料 $\mathrm{d}$ においてはパケット境界及びラ ス境界が他の試料に比べ明瞭に認められる。

\section{$3 \cdot 2$ クリープ特性の旧オーステナイト粒径依存性} $650^{\circ} \mathrm{C}$ に扔ける破断時間の結晶粒径依存性を Fig. 1 に示す. $50 \mu \mathrm{m}$ 以下の細粒側では破断時間は旧オーステ ナイト粒径の増加に伴い直線的に増加する。しかし，旧 オーステナイト粒径が $50 \mu \mathrm{m}$ 以上に大きくなると粒径 の増加に対する破断時間の増加量は細粒側に比べ小さ く, 最大及び最小応力であるそれぞれ $17 \mathrm{kgf} / \mathrm{mm}^{2}$ 及び

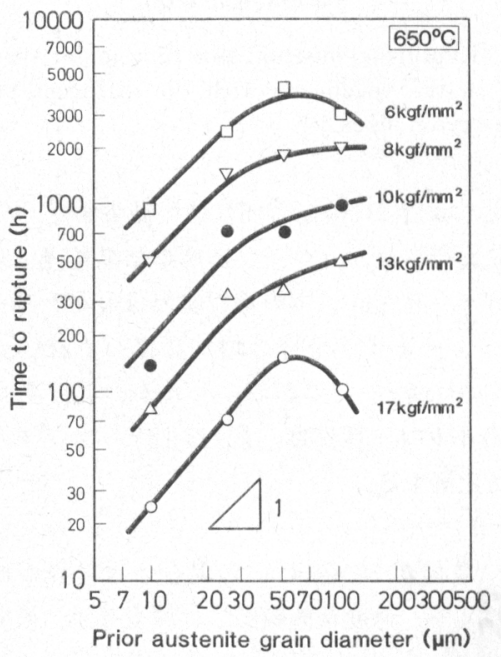

Fig. 1. Time to rupture as a function of prior austenite grain size under five applied stresses.

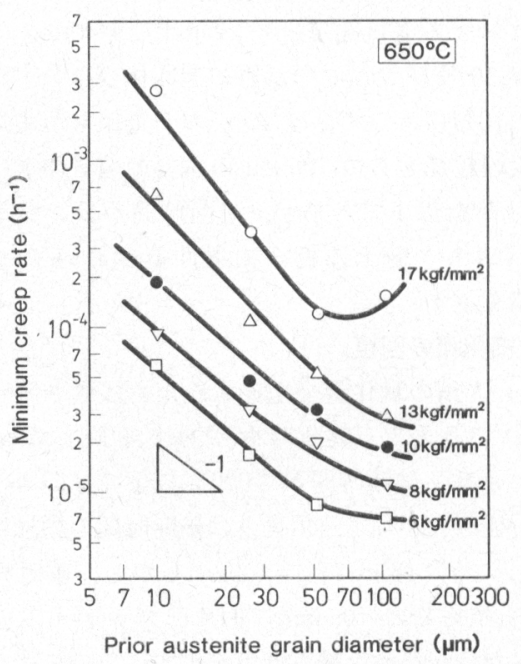

Fig. 2. Minimum creep rate as a function of prior austenite grain size under five applied stresses. 


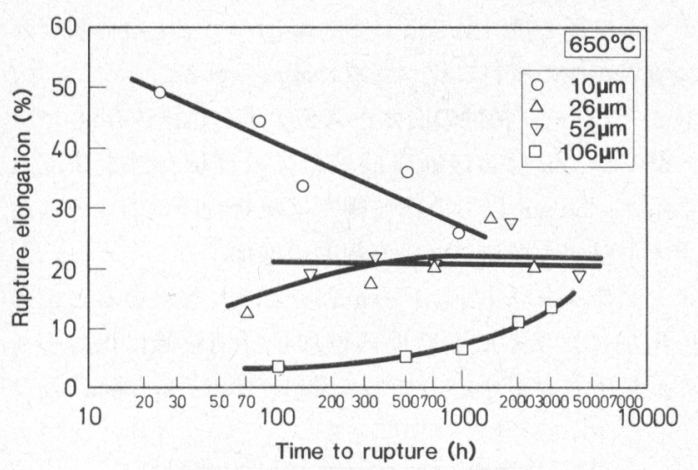

Fig. 3. Rupture elongation as a function of time to rupture in the specimens with the different prior austenite grain sizes.

$6 \mathrm{kgf} / \mathrm{mm}^{2}$ の場合には破断時間は逆に減少する. $650^{\circ} \mathrm{C} に お け る$ 最小クリープ速度の結晶粒径依存性を

Fig. 2 に示す. $50 \mu \mathrm{m}$ 以下の細粒側では最小クリープ速 度は旧オーステナイト粒径の増加に伴い直線的に減少 し，その勾配は約ー1である.したがつて，次式に示 すように最小クリープ速度， $\dot{\varepsilon}_{m}$ は旧オーステナイト粒 径, $d$ に反比例する.

$$
\dot{\varepsilon}_{m} \propto d^{-1} \text {. }
$$

しかし, 粒径が $50 \mu \mathrm{m}$ 以上の場合には粒径が増加し ても最小クリープ速度は直線的には減少せず, 破断時間 の場合と同様，最大及び最小の応力条件下（それぞれ 17 及び $\left.6 \mathrm{kgf} / \mathrm{mm}^{2}\right)$ では最小クリープ速度は増大もし くは一定値を示す.

旧オーステナイト粒径が異なる 4 試料の破断伸びの破 断時間に対する変化を Fig. 3 に示す. 旧オーステナイ 卜粒径が 26 及び $52 \mu \mathrm{m}$ の試料の破断伸びはいずれも破 断時間の長短によらずほほ $20 \%$ の一定值を示す。しか し，最大の粒径をもつ $106 \mu \mathrm{m}$ の試料の破断伸びは短時 間側では $5 \%$ 以下であるが，破断時間が長くなると増 加し，1000 h を超える低応力条件下においては $10 \%$ 以上の值を示す.

\section{$3 \cdot 3$ 微細組織の回復}

$\mathrm{Cr}-\mathrm{Mo}^{-} \mathrm{V}$ 鋼の軟化量を把握するために硬さ測定が通 常行われてきた ${ }^{6)}$. 破断時間に対する硬さの変化を Fig. 4 に示す. 破断時間が $1000 \mathrm{~h}$ 以下では旧オーステ ナイト粒径の大小によらず硬さは破断時間の増加に伴い ほほ同じような傾向で低下する。しかし，破断時間が $1000 \mathrm{~h}$ を超えると $106 \mu \mathrm{m}$ の旧オーステナイト粒径を もつ試料だけが急激な硬さ低下を示す。このことから， クリープ試験時間の増加に伴う微細組織の回復量は $1000 \mathrm{~h}$ 以内においては粒径に依存せず，1000 h を超え

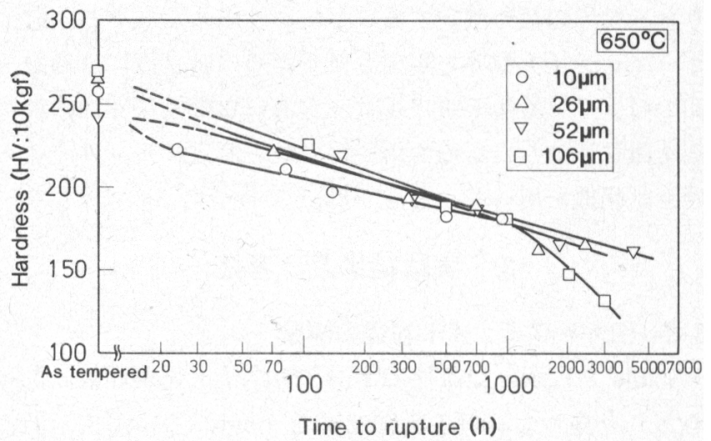

Fig. 4. Hardness against rupture life in the specimens with the different prior austenite grain sizes.
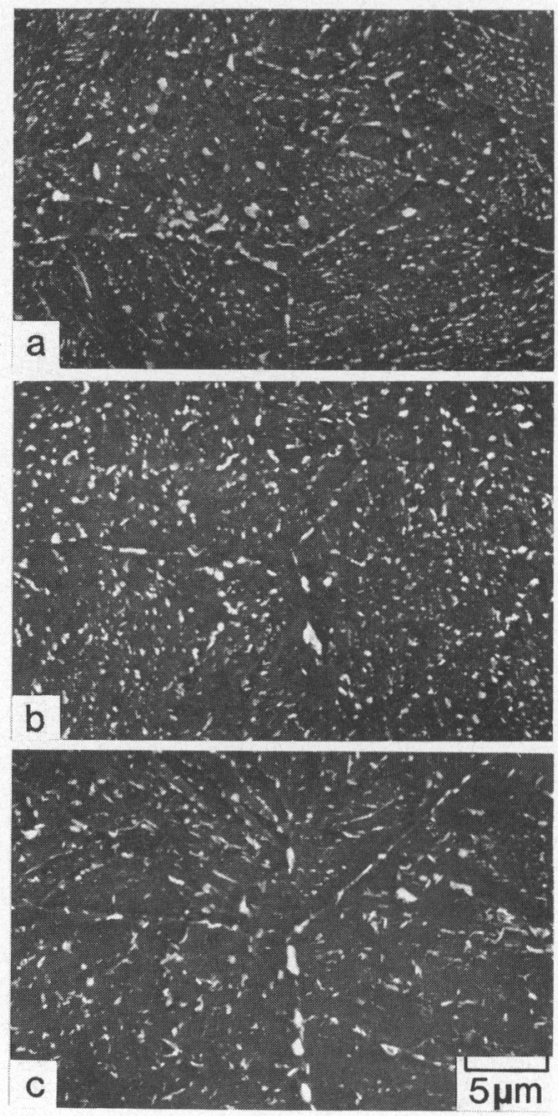

a : $10 \mu \mathrm{m}, t_{i}=25 \mathrm{~h} \quad$ b : $26 \mu \mathrm{m}, t_{i}=130 \mathrm{~h} \mathrm{c} \quad: 52 \mu \mathrm{m}, t_{i}=170 \mathrm{~h}$ Photo. 2. Secondary electron images of the specimens interrupted at $650^{\circ} \mathrm{C}-10 \mathrm{kgf} / \mathrm{mm}^{2}$ with the prior austenite grain diameter of 10,26 and $52 \mu \mathrm{m}$.

ると最大の粒径を持つ $106 \mu \mathrm{m}$ の試料だけが急激な回復 を生じていることが予測される。 


\section{$3 \cdot 4$ クリープ抵抗の旧オーステナイト粒径依存性と組} 織との関係

$3 \cdot 4 \cdot 1$ 細粒側におけるクリープ抵抗の粒径依存性 $650^{\circ} \mathrm{C}$, 応力 $10 \mathrm{kgf} / \mathrm{mm}^{2}$ のクリープ試験をクリープ 速度が最小となる時間域で中断した 10,26 及び $52 \mu \mathrm{m}$ の旧オーステナイト粒径を持つ試料の走査電顕写真を Photo. 2 に示す.いずれの試料においても粒界炭化物 は粗大化しており，旧オーステナイト粒界に沿つて不均 一に生じた微細炭化物の消滅した領域，すなわち前報9 で述べた回復領域が認められる。

そこで,これらの中断材の回復領域の幅を前報9と同 一の手法を用いて測定し，Fig. 5 に示すように回復領 域の幅の旧オーステナイト粒径依存性を調べた。 $50 \mu \mathrm{m}$ 以下の細粒側では, 同一応力であれば最小クリー プ速度を示す時点での回復領域の幅は旧オーステナイト 粒径の大小によらずほぼ一定である.

ところで，前報9にに扔ける $\mathrm{Cr}^{-}-\mathrm{Mo}^{-}-\mathrm{V}$ 鋼の高温時効に 伴うクリープ抵抗の低下と回復領域の幅との関係は旧 オーステナイト粒径が $21 \mu \mathrm{m}$ の試料について得られた 結果である。この場合，次式に示すように最小クリープ 速度 $\dot{\varepsilon}_{m}$ は回復領域の幅, $W$ に比例する。

$$
\dot{\varepsilon}_{m} \propto W
$$

ここで，回復領域の幅，Wは旧オーステナイト粒径の 大小にはほとんど依存しないという本実験結果を併せて 考えると，(1)及び( 2 )式から, 次の関係が成り立つ.

$$
\dot{\varepsilon}_{m} \propto W / d
$$

また, 単位体積当たりの結晶粒界面積, $S$ と結晶粒径と は反比例の関係 $\left(S \propto d^{-1}\right)$ にあり, 次式が求まる.

$$
\dot{\varepsilon}_{m} \propto W \times S \text {. }
$$

(4)式の右辺, $W \times S$ は単位体積当たりの回復領域の 体積率を表している.このことは, $\mathrm{Cr}-\mathrm{Mo}^{-}-\mathrm{V}$ 鋼のクリー プ抵抗が本質的には回復領域の幅ではなく，回復領域の

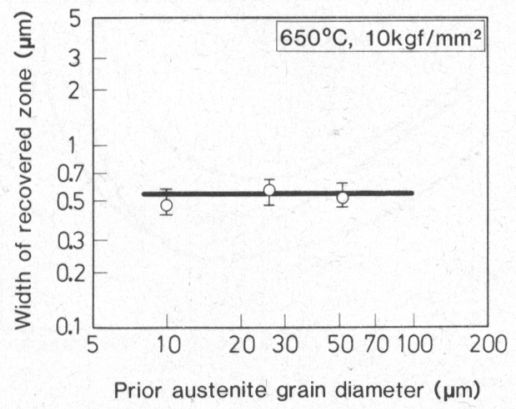

Fig. 5. The width of recovered zone in the specimens interrupted at $650^{\circ} \mathrm{C}-10 \mathrm{kgf} / \mathrm{mm}^{2}$ as a function of prior austenite grain size.
体積率で決定されることを示している。

以上の検討より, $50 \mu \mathrm{m}$ 以下の細粒側において認めら れた旧オーステナイト粒径の増加に伴う最小クリープ速 度の減少は, 粒界面積の減少に対応した回復領域の体積 率の減少によると結論される。また，前報で述べた高温 における応力時効あるいは単純時効材のクリープ抵抗も (4)式において粒界面積が一定であつたために回復領域 の幅で一義的に整理されたが ${ }^{9)}$, 本質的には回復領域の 体積率に対応するとみなすことができる.

$3 \cdot 4 \cdot 2$ 高応力 $\left(17 \mathrm{kgf} / \mathrm{mm}^{2}\right)$ クリープ条件において 粗粒側で認められたクリープ抵抗の低下

本研究で行つた最大応力の $17 \mathrm{kgf} / \mathrm{mm}^{2}$ においては粒 径が $50 \mu \mathrm{m}$ を超えるとクリープ抵抗は低下した (Fig. 2).しかし，Fig. 4 に示したように $17 \mathrm{kgf} / \mathrm{mm}^{2}$ で破断した $106 \mu \mathrm{m}$ の試料 $\left(\boldsymbol{t}_{r}=105 \mathrm{~h}\right)$ と $52 \mu \mathrm{m}$ の試 料 $\left(\boldsymbol{t}_{r}=153 \mathrm{~h}\right)$ の硬さの差はほとんどない。そこで, 両破断材の組織を比較, 検討する.

Photo. 3 に $17 \mathrm{kgf} / \mathrm{mm}^{2}$ で破断した 52 及び $106 \mu \mathrm{m}$ の試料の走查電䫓組織を示す. $52 \mu \mathrm{m}$ の試料 $\mathrm{a}$ に扔いて は粒内に比べ粒界での炭化物の粗大化が顕著であり，粒 界近傍では炭化物の析出密度が低い回復領域が認められ る. $106 \mu \mathrm{m}$ の試料 b の粒内に求ける組織は $52 \mu \mathrm{m}$ で認 められたものと同様であり，また，粒界炭化物の大きさ

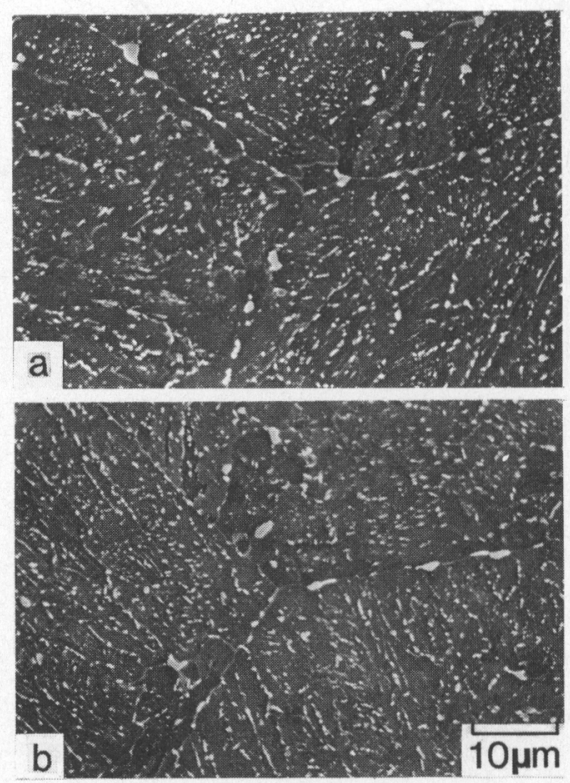

a : $52 \mu \mathrm{m}, t_{r}=153 \mathrm{~h} \quad \mathrm{~b}: 106 \mu \mathrm{m}, t_{r}=105 \mathrm{~h}$

Photo. 3. Secondary electron images of the specimens with the prior austenite grain sizes of 52 and $106 \mu \mathrm{m}$ after crept at $650^{\circ} \mathrm{C}-17 \mathrm{kgf} / \mathrm{mm}^{2}$. 
及び回復領域の幅はいずれも $52 \mu \mathrm{m}$ のものに比べわず

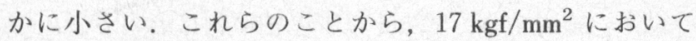
粒径が $50 \mu \mathrm{m}$ を超えるとクリープ抵抗が低下した原因 は微細組織の変化によるとは考えにくい.

Fig. 6 に各試料の $650^{\circ} \mathrm{C}$, 応力 $17 \mathrm{kgf} / \mathrm{mm}^{2}$ における タリープ速度一時間曲線を示す。旧オーステナイト粒径 が $10,26,52 \mu \mathrm{m}$ の試料の順に最小クリープ速度は減 少し，またこれに対応して破断時間は長くなるが, $106 \mu \mathrm{m}$ の試料は遷移域でのクリープ速度が他のいずれ の試料よりも小さいにもかかわらず，最小のクリープ速 度を相対的に短時間側で示す。その結果, $52 \mu \mathrm{m}$ の試料 に比べ破断時間もまた短い。

そこで, $106 \mu \mathrm{m}$ の試料については Fig. 6 中に○印で

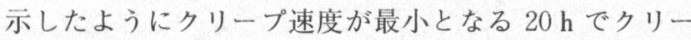
プ試験を中断した. 中断材の反射電子像を Photo. 4 に 示す. 20 ～ $30 \mu \mathrm{m}$ の非常に大きな粒界割れが多数観察さ

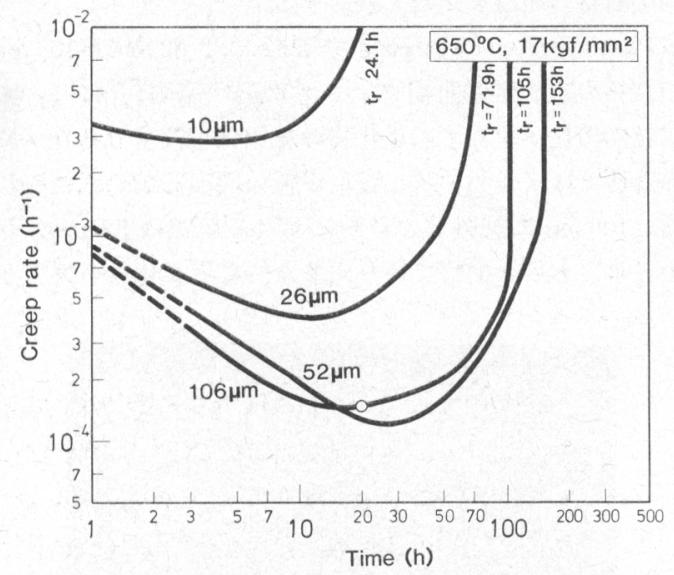

Fig. 6. Creep rate-time curves of the specimens with the different prior austenite grain sizes at $650^{\circ} \mathrm{C}-17 \mathrm{kgf} / \mathrm{mm}^{2}$.

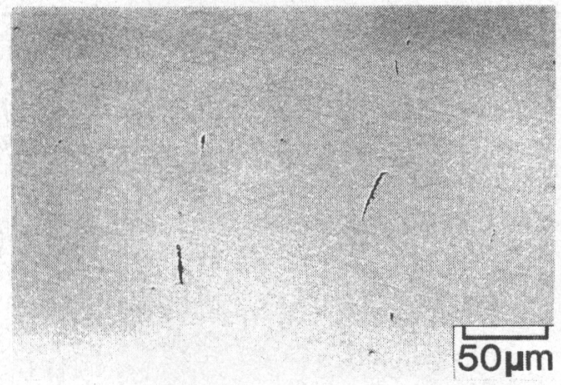

Photo. 4. Reflection electron image of the specimen with the prior austenite grain size of $106 \mu \mathrm{m}$ after interrupting the test at $20 \mathrm{~h}$ at $650^{\circ} \mathrm{C}-17$ $\mathrm{kgf} / \mathrm{mm}^{2}$.
れた.割れは試料断面に均一に分布しているのではなく， 数個の割れが集団をなして隣接した数結晶粒界に形成さ れている.ささらに,この試料の破断伸びは Fig. 3 に示 したように $3.5 \%$ であつた.これらのことから，旧オー ステナイト粒径が $106 \mu \mathrm{m}$ の粗粒材を高応力条件のもと でクリープ試験すると，最小クリープ速度に到達する以 前に旧オーステナイト粒界に割れが発生し，割れの近傍 でさらに別の割れの発生を誘い，有効な断面積が減少し てクリープ速度が増加したものと推論される.

$3 \cdot 4 \cdot 3$ 粗粒側におけるクリープ抵抗の旧オーステナ イト粒径依存性

旧オーステナイト粒径が $50 \mu \mathrm{m}$ を超えると応力 17 $\mathrm{kgf} / \mathrm{mm}^{2}$ ではクリープ抵抗は低下するが, 応力が低く なると $50 \mu \mathrm{m}$ 以上でもクリープ抵抗は増加するように なる.しかし，さらに応力が $6 \mathrm{kgf} / \mathrm{mm}^{2} に$ によ゙低下す るとクリープ抵抗の増加に対する粒径の効果は減少し て，飽和する傾向を示す.

ところで，ある粒径を超えるとクリープ抵抗が低下 ないしは飽和する現象はいくつかの $\gamma$ 単相の合

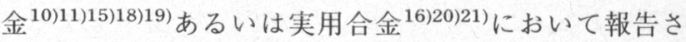
れている。これらは粒界三重点での応力集中により割れ の発生が加速される効果 ${ }^{11)}$, あるいは再結晶粒の形 成 ${ }^{15) 16)}$ によるクリープ抵抗の低下が主なる原因と考え られている. しかし，それらはいずれも高応力側で生ず

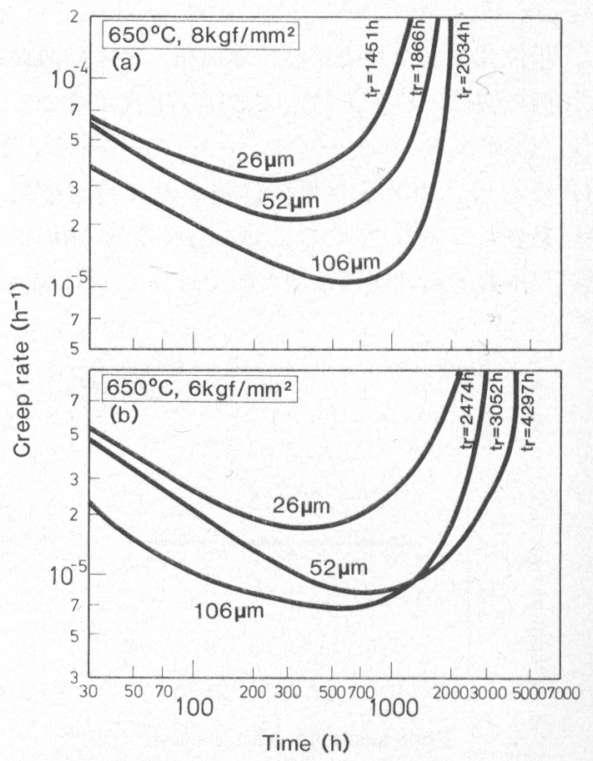

Fig. 7. Creep rate-time curves of the specimens with the different prior austenite grain sizes at $650^{\circ} \mathrm{C}$ under the stresses of 6 and $8 \mathrm{kgf} / \mathrm{mm}^{2}$. 

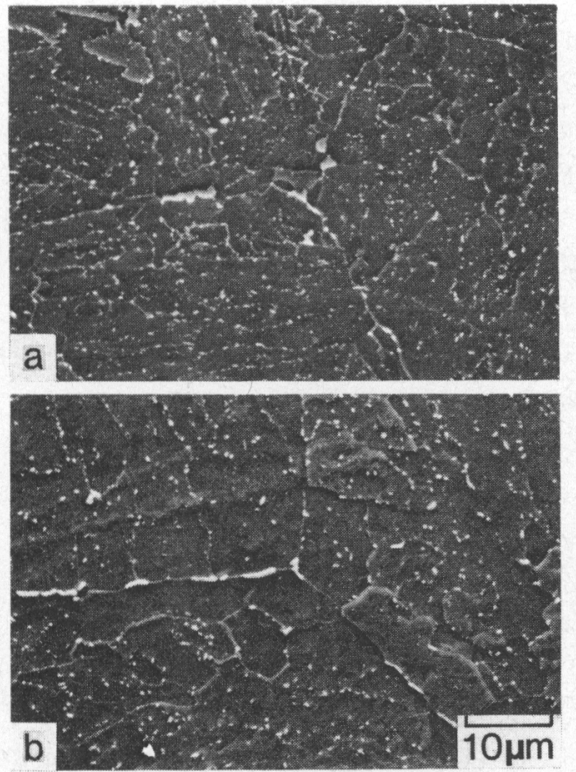

a : $52 \mu \mathrm{m}, t_{r}=4297 \mathrm{~h} \quad$ b : $106 \mu \mathrm{m}, t_{r}=3052 \mathrm{~h}$

Photo. 5. Secondary electron images of the specimens with the prior austenite grain sizes of 52 and $106 \mu \mathrm{m}$ after crept at $650^{\circ} \mathrm{C}-6 \mathrm{kgf} / \mathrm{mm}^{2}$.

る現象である。 そこで本節では，低応力側でこのような 傾向が観察された原因について検討する。

各試料の $650^{\circ} \mathrm{C}$, 応力 $8 \mathrm{kgf} / \mathrm{mm}^{2}$ 及び $6 \mathrm{kgf} / \mathrm{mm}^{2}$ で のクリープ速度-時間曲線を Fig. 7 ( a ), ( b )に示す. (a)に示す応力 $8 \mathrm{kgf} / \mathrm{mm}^{2}$ では旧オーステナイト粒径 の大きなものほどクリープ速度は小さく, より長時間側 でより小さな最小クリープ速度を示す.しかし, 本研究 で行つた最も低応力の $6 \mathrm{kgf} / \mathrm{mm}^{2}$ ( b ) の場合には, 52 $\mu \mathrm{m}$ の試料と $106 \mu \mathrm{m}$ の試料の最小クリープ速度の差は 少ない. また, 後者の最小クリープ速度を示す時間及び 破断時間は前者よりも短くなる.

Photo. 5 に $650^{\circ} \mathrm{C}$, 応力 $6 \mathrm{kgf} / \mathrm{mm}^{2}$ で破断した 52 及 び $106 \mu \mathrm{m}$ の試料の走査電顕組織を示す. $52 \mu \mathrm{m}$ の試料 $\mathrm{a}$ に比べ $106 \mu \mathrm{m}$ の試料 $\mathrm{b}$ は破断時間が短いにもかかわ らず，粒界炭化物はより粗大であり，また旧オーステナ イト粒界に沿つた回復領域の粒内への拡大も顕著であ る.

Photo. 5 と同一試料の透過電顕組織を Photo. 6 に示 す.旧オーステナイト粒径が $106 \mu \mathrm{m}$ の試料 b は $52 \mu \mathrm{m}$ の試料 $\mathrm{a}$ に比べ破断時間は短いが, 前者の旧オーステナ イト粒界近傍で形成されたサブグレイン及びフェライト 粒はラス境界に沿つて著しく粒内へと拡大しており, 試
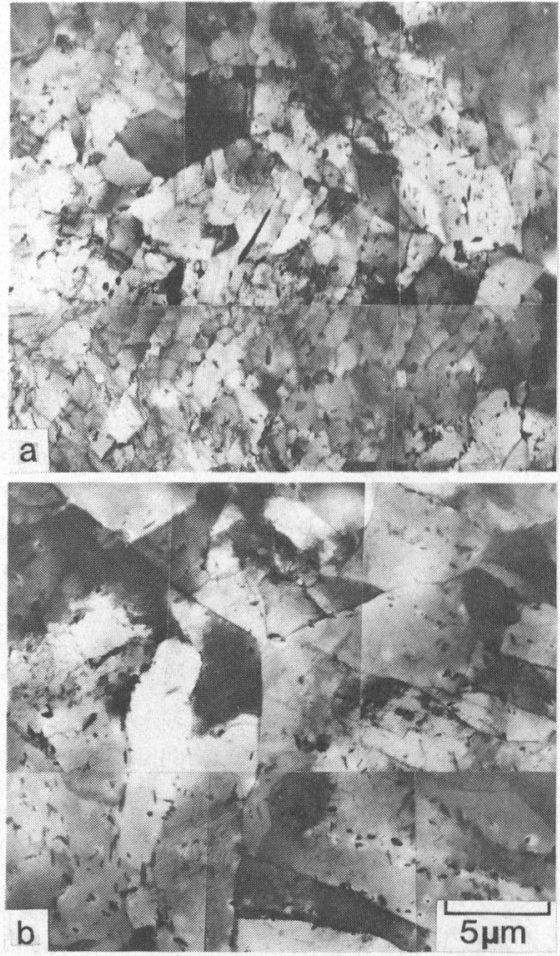

a : $52 \mu \mathrm{m}, t_{r}=4297 \mathrm{~h} \quad$ b: $106 \mu \mathrm{m}, t_{r}=3052 \mathrm{~h}$

Photo. 6. Transmission electron micrographs of the specimens with the prior austenite grain sizes of 52 and $106 \mu \mathrm{m}$, crept at $650^{\circ} \mathrm{C}-6 \mathrm{kgf} / \mathrm{mm}^{2}$.

料全面で転位密度が著しく低下している.

以上の組織観察結果と, (i) $106 \mu \mathrm{m}$ の試料の硬さが 1000 h を超えると急激に低下したこと（Fig. 4)，また (ii)破断伸びは低応力, 長時間側で増加したこと (Fig. 3) を併せて考えると, $106 \mu \mathrm{m}$ の試料では, 粒界三重点で の応力集中により, その近傍での局所的な回復領域の形 成が促進され，これが旧オーステナイト粒界だけではな く, ラス境界に沿つて粒内へと拡大した結果, クリープ 抵抗が急速に低下したものと思われる. 低応力側におい てこのような現象が生じた原因としては,粗粒材の場合, 粒内のラスの形状も粗大化するなどべイナイト組織自体 に不均一性が生じ, それがラス境界に沿つた回復領域の 粒内への拡大を速めている点が重要である. しかし,こ のような粒内での回復現象は粒界に沿つた回復領域があ る程度拡大した後で生ずるため, 長時間を要する.した がつて,このような現象が低応力側で生じたものと推論 される。

以上の結果より，長時間の破断強度を考慮した場合， 
$\mathrm{Cr}-\mathrm{Mo}-\mathrm{V}$ 鎆の旧オーステナイト粒径は $50 \mu \mathrm{m}$ 以下に調 整されるべきであると結論される.

\section{4. 結論}

旧オーステナイト粒径を広い範冊で変化させた $\mathrm{Cr}-\mathrm{Mo}-\mathrm{V}$ 鋼を用い, $650^{\circ} \mathrm{C}$ でのクリープ特性に及ぼす 旧オーステナイト粒径の影響を調べ，それがどのような 組織変化と関連するかを検討した結果，以下の結論を得 た。

1 ）旧オーステナイト粒径の増加に伴いクリープ抵抗 は増加し, $50 \mu \mathrm{m}$ 以下の範囲では最小クリープ速度は旧 オーステナイト粒径に反比例する．しかし，粒径が約 $50 \mu \mathrm{m}$ を超えるとその程度は小さくなり, 高応力及び低 応力ではそれぞれ低下あるいは飽和する傾向が認められ る.

2 ) 破断伸びは旧オーステナイト粒径が大きなものほ ど小さく, $106 \mu \mathrm{m}$ の試料では高応力, 短時間側で $5 \%$ 以下の著しく小さな値を示すが，破断時間の増加に伴つ て増加する。

3 ) 硬さは破断時間の増加に伴い単調に低下し，破断 時間が $1000 \mathrm{~h}$ 以下の範囲では旧オーステナイト粒径の 大小による差異は認められない。しかし，106 $\mu \mathrm{m}$ の試 料の硬さだけが $1000 \mathrm{~h}$ を超えると急激に低下する.

4 ） $50 \mu \mathrm{m}$ 以下の細粒材において, 同一応力で中断し た試料で認められる回復領域の幅は旧オーステナイト粒 径の大小によらずほぼ同じである.

5 ) 高応力, 短時間側で破断した $106 \mu \mathrm{m}$ の試料では, 数個の粗大な割れが観察された。また，割れは均一に分 布しているのではなく，集団をなして隣接した数結晶粒 界に形成されていた。 さらに，低応力で破断した試料で は粒界近傍での局所的な回復領域の形成及びそれのラス 境界に沿つた粒内への桩大が粒径の小さい試料に比べ, より著しい.

6）1）及び 4 ）の結果より，粒径が $50 \mu \mathrm{m}$ 以下に おける最小クリープ速度と旧オーステナイト粒径との関 係を検討して, 旧オーステナイト粒径の増加に伴う最小 クリープ速度の減少は粒界面積の減少による回復領域の 体積率の減少と対応することを明らかにし, $\mathrm{Cr}-\mathrm{Mo}-\mathrm{V}$ 鋼のクリープ抵抗は回復領域の幅ではなく，本質的には 体積率によつて決定されることを明らかにした。

7 ）旧オーステナイト粒径が $50 \mu \mathrm{m}$ を超える粗粒側 では，高応力の場合，クリープ抵抗が低下するのは最小
クリープ速度を示す以前に割れの発生・伝播が進行する ことにより，一方，応力がある值以下に低下し長時間を 経るとクリープ抵抗の増加が再び認められなくなるのは 粒径の増加に伴つて組織の不均一性が増加し，回復領域 が粒内へと急速に拡大するためと結論した。ささらに，こ れらの結果より，長時間での強度を考慮した場合， $\mathrm{Cr}-\mathrm{Mo}-\mathrm{V}$ 鋼の旧オーステナイト粒径は $50 \mu \mathrm{m}$ 以下に調 整されるべきであると結論した.

終わりに, 本研究に協力された千葉工業大学·学生 (現 •扶桑軽合金) 島津浩司氏に感謝します。さらに，本研 究の一部は科学技術庁, 科学振興調整費によつたことを 付記して，謝意を表します。

\section{文献}

1) H. R. TIPLER and B. E. Hopkins: Met. Sci., 109 (1976), p. 47

$2)$ N. Shin-Ya and S. R. Keown: Met. Sci., 13 (1979), p. 107

3 ) $K . R$. Williams and B. Wilshire: Mater. Sci. Eng., 38 (1979), p. 199

4 ) C. J. Bolton, B. F. Dyson and K. R. Williams: Mater. Sci. Eng., 46 (1980), p. 231

5 ) K. R. Williams and B. WilshiRe: Mater. Sci. Eng., 47 (1981), p. 151

6 ) 山田政之，渡辺 修，小松周一，中村新一: 学振 123 委 研究報告, 22 (1981)，p. 123

7 ）松尾 孝，木佐貫哲也，田中良平，小松周一: 鉄と鋼，70 (1984), p. 565

8 ）木村一弘，木佐貫哲也，小松周一，松尾 孝，田中良平： 鉄と鋼, 71 (1985), p. 1803

9 ）木村一弘，松尾 孝，菊池 實，田中良平: 鉄と鋼，72 (1986), p. 474

10) F. Garofalo, $W . F$. Domis and $F$. Von Gemmingen: Trans. Metall. Soc. AIME, 230 (1964), p. 1460

11）星田達男: 修士論文 (東京工業大学) (1976)

12）仲西恒雄，松本紀昭，河田 修: 日本金属学会誌，41 (1977), p. 263

13）藤岡順三，村瀬公一，松田昭三，喜多 清: 学振 123 委 研究報告, 19 (1978), p. 165

14) D. MCLEan: Metall. Trans., 7 (1976), p. 1225

15）近藤義宏，松尾 孝，篠田隆之，田中良平: 鉄と鋼，65 (1979), p. 896

16）近藤義宏，松尾 孝，篠田隆之，田中良平: 鉄と鋼，67 (1981), p. 1805

17) $K$. Kimura, $N$. Ohi, $K$. Shimazu, $T$. Matsuo, $R$. Tanaka and M. KIKUCHI: Scripta Metall., 21 (1987), p. 19

18) $W$. $R$. Johnson, $C$. $R$. BarretT and $W$. D. Nix: Metall. Trans., 3 (1972), p. 695

19）西川 廣, 市原留吉, 松尾 孝, 田中良平: 学振 123 委 研究報告, 20 (1979), p. 19

20) P. Shahinian and J. R. LANE: Trans. ASM, 45 (1953), p. 177

21）田村 学，亀村佳樹，渡辺力蔵，千葉芳孝: 鉄と鋼，65 (1979), p. 1022 